\title{
Annual $\mathrm{CO}_{2}$ budget and seasonal $\mathrm{CO}_{2}$ exchange signals at a high Arctic permafrost site on Spitsbergen, Svalbard archipelago
}

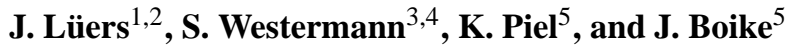 \\ ${ }^{1}$ University of Bayreuth, Department of Micrometeorology, 95440 Bayreuth, Germany \\ ${ }^{2}$ Bayreuth Center of Ecology and Environmental Research, BayCEER, Bayreuth, Germany \\ ${ }^{3}$ Department of Geosciences, University of Oslo, Boks 1047 Blindern, 0316 Oslo, Norway \\ ${ }^{4}$ Center for Permafrost (CENPERM), Department of Geography and Geology, University of Copenhagen, \\ 1350 Copenhagen, Denmark \\ ${ }^{5}$ Alfred Wegener Institute for Polar and Marine Research, 14473 Potsdam, Germany \\ Correspondence to: J. Lüers (johannes.lueers@uni-bayreuth.de)
}

Received: 30 December 2013 - Published in Biogeosciences Discuss.: 23 January 2014

Revised: 29 September 2014 - Accepted: 6 October 2014 - Published: 24 November 2014

\begin{abstract}
The annual variability of $\mathrm{CO}_{2}$ exchange in most ecosystems is primarily driven by the activities of plants and soil microorganisms. However, little is known about the carbon balance and its controlling factors outside the growing season in Arctic regions dominated by soil freeze/thaw processes, long-lasting snow cover, and several months of darkness. This study presents a complete annual cycle of the $\mathrm{CO}_{2}$ net ecosystem exchange (NEE) dynamics for a high Arctic tundra area at the west coast of Svalbard based on eddy covariance flux measurements. The annual cumulative $\mathrm{CO}_{2}$ budget is close to $0 \mathrm{~g} \mathrm{C} \mathrm{m}^{-2} \mathrm{yr}^{-1}$, but displays a strong seasonal variability. Four major $\mathrm{CO}_{2}$ exchange seasons have been identified. (1) During summer (snow-free ground), the $\mathrm{CO}_{2}$ exchange occurs mainly as a result of biological activity, with a dominance of strong $\mathrm{CO}_{2}$ assimilation by the ecosystem. (2) The autumn (snow-free ground or partly snow-covered) is dominated by $\mathrm{CO}_{2}$ respiration as a result of biological activity. (3) In winter and spring (snowcovered ground), low but persistent $\mathrm{CO}_{2}$ release occurs, overlayed by considerable $\mathrm{CO}_{2}$ exchange events in both directions associated with high wind speed and changes of air masses and atmospheric air pressure. (4) The snow melt season (pattern of snow-free and snow-covered areas) is associated with both meteorological and biological forcing, resulting in a carbon uptake by the high Arctic ecosystem. Data related to this article are archived at http://doi.pangaea.de/ 10.1594/PANGAEA.809507.
\end{abstract}

\section{Introduction}

Northern terrestrial ecosystems have an important role in the earth's climate system due to their ability to sequester the greenhouse gas carbon dioxide (Graven et al., 2013; Shaver et al., 2007). However, our understanding of the transient carbon dynamics of a thawing Arctic remains rudimentary. Due to the difficulties involved in collecting measurements in cold, remote regions, there have been very few year-long studies of net $\mathrm{CO}_{2}$, water, and energy exchange using micrometeorological methods (e.g., Euskirchen et al., 2012; Lund et al., 2012). However, it is critical to improve the understanding of the variations in carbon and water fluxes across the different types of permafrost tundra ecosystems in order to be able to validate and predict future carbon and water budgets in coupled earth system models (Shaver et al., 2007)

The annual carbon budgets of Arctic ecosystems are not only characterized by growing season exchanges, but also by losses and gains that occur during the transition seasons of spring (snowmelt/soil thaw) and autumn (senescence/soil freeze) as shown by several studies (e.g., Marushchak et al., 2013; Heikkinen et al., 2004), particularly for Siberia (Corradi et al., 2005), Alaska (e.g., Kwon et al., 2006; Euskirchen et al., 2012), Greenland (e.g., Soegaard et al., 2000), Svalbard (Lloyd, 2001a, b), Canada (Humphreys and Lafleur, 2011), and northern Scandinavia (e.g., Aurela et al., 2004). 
Most ecosystems experience interannual and across-site variability in $\mathrm{CO}_{2}$ exchange that is primarily driven by growing season dynamics and moisture conditions (Lloyd et al., 2001; Uchida et al., 2009). However, in climatic regions dominated by snow, ice, and soil freeze/thaw processes, interactions between permafrost and atmosphere during the snow-covered dark winter months and early (pre-melt) spring may also make a significant contribution to the carbon cycle. Estimated winter $\mathrm{CO}_{2}$ releases have been reported to make up between $20 \%$ and $40 \%$ of an ecosystem's annual carbon loss (Zimov et al., 1996; Fahnestock et al., 1999; Elberling and Brandt, 2003; Euskirchen et al., 2012).

Several studies have shown growing season $\mathrm{CO}_{2}$ exchange in tundra ecosystems to be closely related to the timing of snowmelt, with earlier snowmelt resulting in a greater uptake of atmospheric $\mathrm{CO}_{2}$ by the ecosystem. Cumulative growing season net ecosystem exchange (NEE) values between $-1.4 \mathrm{~g} \mathrm{C} \mathrm{m}^{-2}$ and $-23.3 \mathrm{~g} \mathrm{C} \mathrm{m}^{-2}$ have been reported for wet tundra by Soegaard and Nordstroem (1999), Nordstroem et al. (2001), and Tagesson et al. (2012), and for a high Arctic heath tundra ecosystem by Groendahl et al. (2007), and Lund et al. (2012). Previously published values for winter $\mathrm{CO}_{2}$ release in Alaska range from $+2 \mathrm{~g} \mathrm{C} \mathrm{m}^{-2} \mathrm{yr}^{-1}$ for tussock tundra in northern Alaska (Fahnestock et al., 1998) to +111 to $+189 \mathrm{~g} \mathrm{C} \mathrm{m}^{-2} \mathrm{yr}^{-1}$ at sites in northern and central Alaska (Grogan and Chapin, 1999). Multiyear groundbased carbon budget analyses from the Arctic tundra and boreal forest sites show high levels of spatial and temporal variability (Johansson et al., 2006). Aurela et al. (2004) reported that a fen at a sub-Arctic site in Kaamanen (northern Finland) acted as a sink for atmospheric $\mathrm{CO}_{2}$, with a mean NEE rate of $-22 \mathrm{~g} \mathrm{C} \mathrm{m}^{-2} \mathrm{yr}^{-1}$, determined from a 6year data set. Carbon balances reported for sites on the North Slope of Alaska (68 to $71^{\circ} \mathrm{N}$ ) range from an accumulation of $-109 \mathrm{~g} \mathrm{C} \mathrm{m}^{-2} \mathrm{yr}^{-1}$ (Chapin et al., 1980) to a release of more than $+200 \mathrm{~g} \mathrm{C} \mathrm{m}^{-2} \mathrm{yr}^{-1}$ (Oechel et al., 1993). A very large interannual variability in the $\mathrm{CO}_{2}$ ecosystem exchange was reported by Schuur et al. (2009) from a sub-Arctic site with extensive thawing of permafrost, ranging from a source of $\mathrm{CO}_{2}$ to the atmosphere (at $\left.+80 \mathrm{~g} \mathrm{C} \mathrm{m}^{-2} \mathrm{yr}^{-1}\right)$ in 1 year to a sink (at $-40 \mathrm{~g} \mathrm{C} \mathrm{m}^{-2} \mathrm{yr}^{-1}$ ) in the following year. This considerable interannual and inter-site variability in conjunction with the lack of year-round micrometeorological studies makes it challenging to compile a coherent picture of the factors driving NEE, with conclusions based on a multitude of short-term $\mathrm{CO}_{2}$ flux studies.

A year-round carbon exchange study on continuous permafrost Arctic tundra using the eddy covariance method was carried out by Euskirchen et al. (2012), who investigated three tundra ecosystems (heath tundra, tussock tundra, and wet sedge tundra) in Imnavait Creek, Alaska. Their study showed that, despite interannual and seasonal variability, the net $\mathrm{CO}_{2}$ accumulation during the growing season was generally lost through respiration during the snow-covered months of September-May so that these ecosystems were net sources of $\mathrm{CO}_{2}$.

There is a critical need to improve our understanding of the variations in carbon and water fluxes across the different types of tundra in order to be able to predict future carbon and water budgets. In this paper we present a full annual cycle of the carbon dynamics at a high Arctic site underlain by permafrost that is currently experiencing warming (Isaksen et al., 2007).

\section{Materials and methods}

\subsection{Study site}

The investigations were carried out in the high Arctic Bayelva River catchment (Fig. 1), close to Ny-Ålesund on Spitsbergen Island in the Svalbard archipelago $\left(78^{\circ} 55^{\prime} \mathrm{N}\right.$, $11^{\circ} 57^{\prime} \mathrm{E}$ ), where continuous permafrost underlies the unglaciated coastal areas to a depth of about $100 \mathrm{~m}$ (Humlum, 2005). The West Spitsbergen Ocean Current, a branch of the North Atlantic Current, warms this area to an average air temperature of about $-13{ }^{\circ} \mathrm{C}$ in January and $+5{ }^{\circ} \mathrm{C}$ in July, and provides about $400 \mathrm{~mm}$ of precipitation annually, falling mostly as snow between September and May. In a bioclimatic context, the area is a semi-desert ecosystem and not wetland or heath tundra (Uchida et al., 2009). Significant warming of air temperatures has been detected since 1960 , which is generally attributed to changes in the radiation budget and in atmospheric circulation patterns (Hanssen-Bauer and Førland, 1998). This warming is also reflected in the permafrost temperatures, as recorded from boreholes (Isaksen et al., 2001, 2007).

Over the past decade the Bayelva catchment has been the focus of intensive investigations on soil and permafrost conditions (Roth and Boike, 2001; Boike et al., 2008; Westermann et al., 2010, 2011), the surface energy balance (Boike et al., 2003; Westermann et al., 2009a, b; Lüers and Boike, 2013), and micrometeorological processes controlling the surface gas and energy exchange (Lüers and Bareiss, 2010, 2011, 2013). The catchment area is bordered by two mountains, Zeppelinfjellet and Scheteligfjellet, between which the glacial Bayelva River originates from the two branches of the glacier Brøggerbreen. The terrain flattens out to the north of the study site and about $1 \mathrm{~km}$ downstream, the Bayelva River flows into the Kongsfjorden and the Arctic Ocean. Within the catchment and the footprint of the flux measurements, areas of sparse vegetation alternate with exposed soil and sand, or rock fields. Typical permafrost features such as mud boils and non-sorted circles are found in many parts of the study area.

The Bayelva soil and climate monitoring station, which is located on top of the hill Leirhaugen ( $25 \mathrm{~m}$ a.s.l.), has been recording climatological parameters and permafrost temperatures since 1998, while an eddy flux tower was constructed 


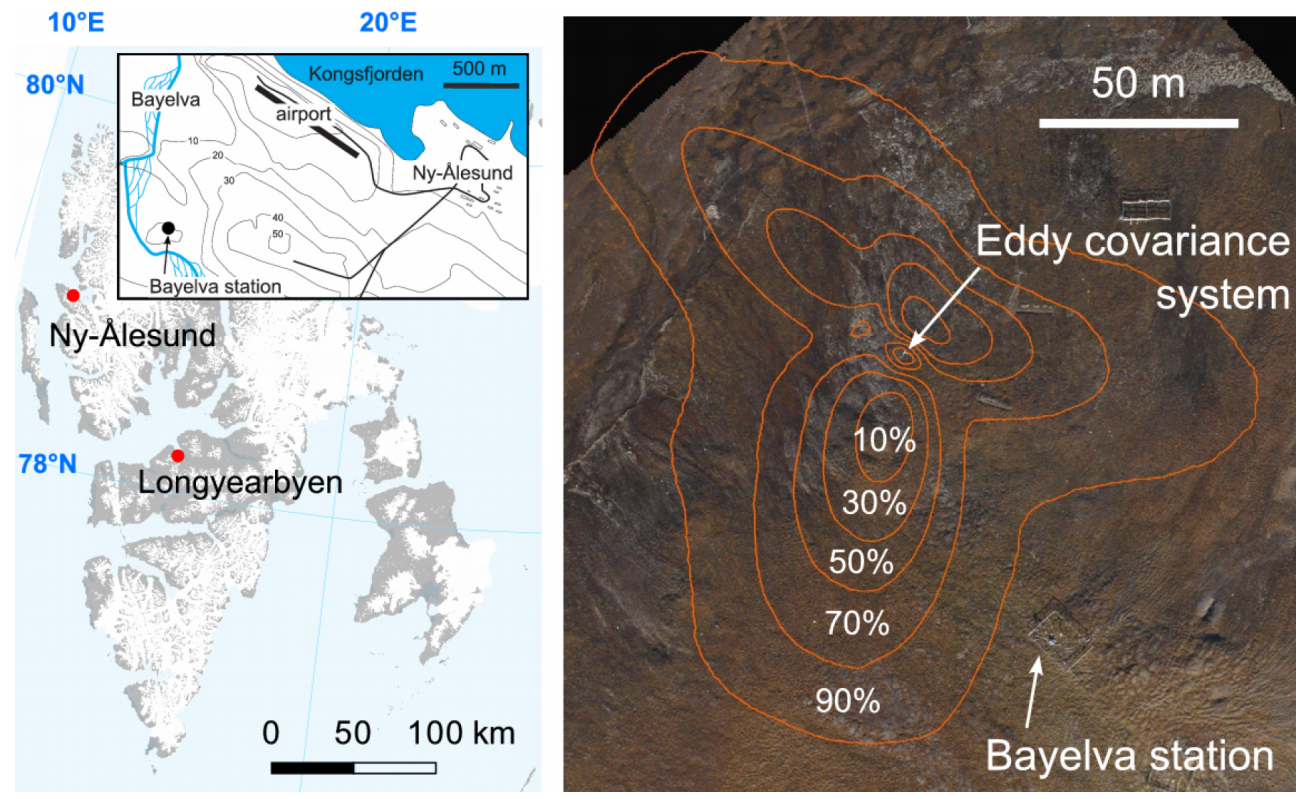

Figure 1. The left panel shows the location of Ny-Ålesund on Svalbard; inset: map of the wider study area with Bayelva station. The right panel shows an orthorectified aerial photo with all installations and average footprint of the eddy covariance system from 1 July to 30 September 2008 (based on Westermann et al., 2009a), with fractions of the total flux originating within the respective contours.

on the gentle $\left(<5^{\circ}\right)$ southern slope of the hill in 2007 (Westermann et al., 2009a). This flux measurement complex consists of a CSAT3 ultrasonic anemometer (Campbell Scientific Ltd.) for measuring turbulence variations of all three wind vectors and sonic temperature, and a LI-7500 open-path gas analyzer (LI-COR Biosciences) for measuring $\mathrm{CO}_{2}$ and $\mathrm{H}_{2} \mathrm{O}$ concentrations ( $45^{\circ}$ tilted position). Both instruments are calibrated by the manufactures at least once a year. The measurement height is $2.9 \mathrm{~m}$ a.g.l. during the snow-free season. The snow height around the station is continuously monitored by an SR50 sonic ranging sensor (Campbell Scientific Ltd.).

The dominant ground pattern around and within the footprint area flux station consists of non-sorted soil circles. The bare soil circle centers are about $1 \mathrm{~m}$ in diameter, surrounded by a vegetated rim consisting of a mixture of low vascular plants including various species of grass and sedge (Carex spp., Deschampsia spp., Eriophorum spp., Festuca spp., Luzula spp.), catchfly, saxifrage, willow, some other locally common species (Dryas octopetala, Oxyria digyna, Polygonum viviparum), and unclassified species of moss and lichen (Ohtsuka et al., 2006; Uchida et al., 2009). The vegetation cover at the measurement site was estimated to be approximately $60 \%$, with the remainder being bare soil with a small proportion of stones (Lloyd et al., 2001). The silty clay soil has a low organic content, with volumetric fractions of less than $10 \%$ (Boike et al., 2008).

\subsection{Evaluation of $\mathrm{CO}_{2}$ fluxes}

The eddy covariance data for 12 months from March 2008 to March 2009 were processed with the internationally standardized TK2 eddy covariance software package (Mauder et al., 2008; Mauder and Foken, 2004, 2011), which produces quality-classified mean values (in our case $30 \mathrm{~min}$ aggregated $\mathrm{CO}_{2}$ fluxes) from the high-frequency data applying, for example, spike detection (Vickers and Mahrt, 1997), correction of spectral loss (Moore, 1986), determination of the time delay between sensors, and correction for density fluctuations (Webb et al., 1980).

This flux-calculating strategy has been successfully applied in major field experiments outside the Arctic region such as the Energy Balance Experiment (EBEX-2000; Mauder et al., 2007; Oncley et al., 2007), the Lindenberg Inhomogeneous Terrain - Fluxes between Atmosphere and Surface: a long-term Study (LITFASS-2003; Mauder et al., 2006), and the Convective and Orographically-induced Precipitation Study (Eigenmann et al., 2011), as well as within the Arctic region (Arctic Turbulence Experiment ARCTEX-2006, 2009: Lüers and Bareiss, 2010, 2011; Westermann et al., 2009a; Jocher et al., 2012). A quality assessment procedure, comprised of a steady-state test (trend conditions) and an integral turbulence characteristics test (to assess the development of turbulent conditions) was employed following the classification procedure proposed by Foken and Wichura (1996) and further developed by Foken et al. (2004) and Lüers and Bareiss (2011). Compared to a simple friction velocity threshold criterion, this quality 
assessment leads to an increase in the number of valid NEE data, especially during weak turbulent exchange conditions (Ruppert et al., 2006), because turbulence still exists even at low friction velocities under steady-state conditions and during intermittent turbulence.

The steady-state test indicated generally high-quality measurement conditions for the Bayelva data set. Most of the momentum fluxes (i.e., $98 \%$ ) and $92 \%$ of the sensible heat fluxes were classified as high quality. The stationarity assumption was fulfilled for $90 \%$ of the water vapor flux (latent heat) and $92 \%$ of the $\mathrm{CO}_{2}$ fluxes. Most of the low-quality classes in the steady state test occurred during periods of very stable atmospheric stratification (during winter, spring, and autumn), and also during storm, rain, and snowfall events. The integral turbulence characteristics test showed for $98 \%$ of all cases that the turbulence of the vertical wind fluctuation was well developed and suitable for reliable $\mathrm{CO}_{2}$ flux calculations.

A wind-direction (fetch)-dependent error - affecting in particular the vertical wind vector component - can occur in the hilly terrain of the Bayelva site in response to the sensor geometry, its position, and its orientation with respect to the topography-dependent wind flow field (Foken et al., 2012; Finnigan et al., 2003). To minimize this tilt error, a three dimensional coordinate system transformation by matrix multiplication was applied to the Bayelva data set, using the planar fit method of Wilczak et al. (2001). This method ideally results in a vertical wind vector of zero, averaged over periods between 1 and 3 weeks. For most of these periods, the mean bias offset between the measured and fitted planes of the wind flow at Bayelva during 2008-2009 was acceptable and close to $0.01 \mathrm{~m} \mathrm{~s}^{-1}$. A footprint analysis by Westermann et al. (2009a) suggests an undisturbed footprint area with the flow paths of the main wind directions unobstructed by artificial structures (Fig. 1). A still unresolved, but potentially important source of errors in particular during winter conditions is the heat generated by the sensor body of the LI7500 open-path gas analyzer, which may generate convection within the sampling volume (Lafleur and Humphreys, 2007). The correction methods proposed by Burba et al. (2008) and Burba (2013) yield unrealistic flux values for the Bayelva data set so that we chose not to apply this correction (see Appendix A for details).

\subsection{Error filtering and gap filling}

Following Papale et al. (2006), we used an expanded multistep error filter algorithm to statistically examine the aggregated time series of flux and meteorological data for outliers and inhomogeneities. After discarding flux values with low TK2 quality flags according to the quality classification system of Foken and Wichura (1996), an adjustable multi-step error filter including a status-or-threshold value check (i.e., the LI-7500 diagnostic feature) and a quantile and standard deviation filter was applied to detect and remove any major outliers.

In total, $27 \%$ of all possible flux data were discarded and had to be gap filled. Approximately $1 \%$ of the flux data were rejected due to low TK2 quality and $3 \%$ were eliminated by the statistical outlier check, typically distributed over very small gaps of only one or two 30 min values. Otherwise, the most common gap sizes were between 1 and $2 \mathrm{~h}$, or between 1 and 2 days (together comprising $16 \%$ of all flux data), in most cases related to snow and/or rain events. Caused by malfunctions in the eddy covariance system, the flux measurements were interrupted for 5 days in July (9-13 July 2008), for 16 days in October 2008 (2-18 October), and for 4 days each in February and March 2009 (18-21 February and 5-8 March). These periods comprise about $7 \%$ of the entire flux data set. Finally, during a 5week period from 1 January to 6 February 2009, the highfrequency $20 \mathrm{~Hz}$ records were not stored because of a memory card error so processing with the TK2 software package was not possible. However, the pre-calculated $30 \mathrm{~min}$ flux data from the data logger's internal Campbell Scientific eddy covariance software were available and could be fitted into the time series without any major gaps.

The small gaps of one or two 30 min values were filled by linear regression with a window size of four values (two before the gap, and two after). To fill the medium-sized gaps (maximum length of 2 days, $58 \%$ of all missing data) and the four large gaps (July and October 2008, February and March 2009) the missing flux data were parameterized with the Michaelis-Menten light response function for plants (in the narrow sense of $\mathrm{CO}_{2}$ assimilation by plants, Michaelis and Menten, 1913; Falge et al., 2001), which relates $\mathrm{CO}_{2}$ exchange to incoming shortwave radiation recorded at the Bayelva climate station.

We applied a 60-day data binning from 13 March 2008 (day 1) to 31 March 2009 (day 384), resulting in six intervals. A reasonable fit of the light response function was achieved only during the snow-free growing season period days 121 to 181 (11 July-9 September 2008). The estimated saturation flux (NEE) was $-0.92 \mu \mathrm{mol} \mathrm{m}{ }^{-2} \mathrm{~s}^{-1}$, with a standard error of 0.03 and a correlation coefficient $R^{2}$ of 0.48 between the parameterized NEE and measured (but smoothed) flux values (Gaussian low-pass filter, 10-day window). With this approach it was possible to fill the data gaps between June and October. For the rest of the year, when there was full snow coverage and/or no sunlight, no significant correlation was found between meteorological parameters (e. g. wind or net radiation) and the net $\mathrm{CO}_{2}$ exchange between the atmosphere and the snow pack. The 4-day gaps in February and March 2009 were therefore statistically filled using smoothed (running average) measured data from 2 days before and 2 days after the gap. 

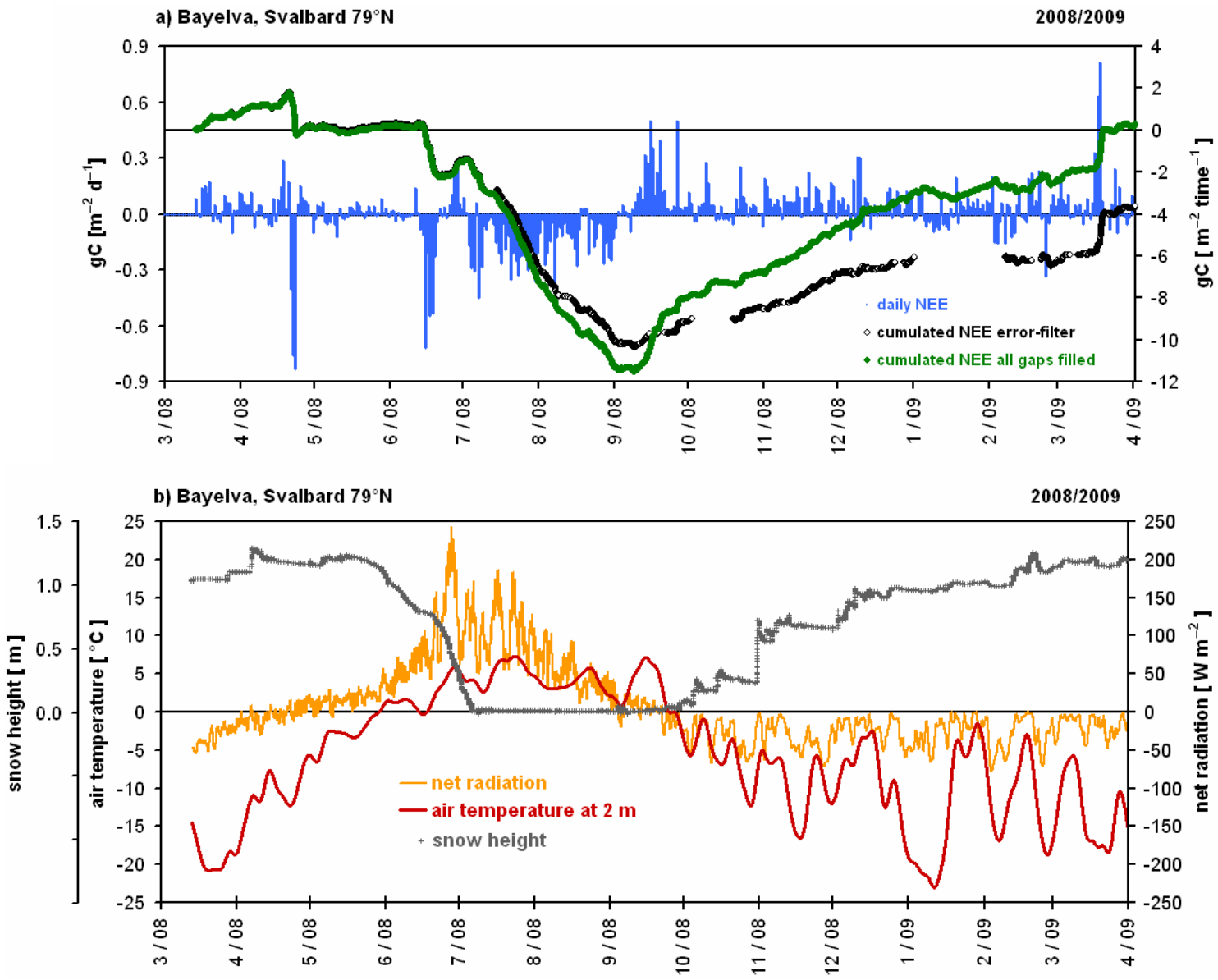

Figure 2. Cumulative net ecosystem exchange (NEE) of carbon dioxide measured at the Bayelva Eddy Flux Station, Svalbard, and calculated using standard eddy covariance software package (a). The blue bars show daily net $\mathrm{CO}_{2}$ flux in $\left[\mathrm{g} \mathrm{C} \mathrm{m}^{-2}\right.$ day $^{-1}$ ]; black dots (NEE fluxes verified by the error filter) and green dots (gap-filled final NEE data set) both annual budget (accumulation between March 2008 and March 2009, [ $\mathrm{g} \mathrm{C} \mathrm{m}^{-2}$ time $^{-1}$ ]). Meteorological measurements (b). Snow height (gray crosses) in meters [m], smoothed air temperatures at $2 \mathrm{~m}$ a.g.l. (red line) in $\left[{ }^{\circ} \mathrm{C}\right]$, smoothed net radiation (orange line) in $\left[\mathrm{W} \mathrm{m}^{-2}\right]$.

\section{Results}

\subsection{The annual $\mathrm{CO}_{2}$ budget}

Figure 2 displays the quality-controlled and gap-filled annual and daily cumulative $\mathrm{CO}_{2}$ budget and related meteorological parameters between March 2008 and March 2009, with a marked effect of error detection and gap filling. An annual budget of close to $0.0 \mathrm{~g} \mathrm{C} \mathrm{m}^{-2} \mathrm{yr}^{-1}$ was found for the Bayelva catchment over the study period. The annual budget can be broken down into four main seasons, with the study area acting as a net sink during snow ablation (mid-May to end of June, $-1.4 \mathrm{~g} \mathrm{C} \mathrm{m}^{-2}$ ) and the snow free summer season (July and August, $-10 \mathrm{~g} \mathrm{C} \mathrm{m}^{-2}$ ), and a net source in autumn (September and October, $+4.6 \mathrm{~g} \mathrm{C} \mathrm{m}^{-2}$ ) and during winter (April 2008, November 2008 to March 2009, $+6.4 \mathrm{~g} \mathrm{C} \mathrm{m}^{-2}$ ). These periods roughly correspond to the characteristic heat and energy balance periods identified for this site (Westermann et al., 2009a).
In 2008, the snowmelt period started in the last week of May and terminated between 20 June and 6 July. The $\mathrm{CO}_{2}$ flux during intensive snowmelt was mainly directed upward (release) into the atmosphere (with positive flux rates of up to $+0.3 \mathrm{~g} \mathrm{C} \mathrm{m}^{-2} \mathrm{day}^{-1}$ ) and had a distinct diurnal character, with higher positive values for $\mathrm{CO}_{2}$ release at noon and in the afternoon.

Directly after snowmelt the tundra ecosystem changed into a $\mathrm{CO}_{2}$ sink (with negative flux rates of up to $-0.4 \mathrm{~g} \mathrm{C} \mathrm{m}^{-2}$ day $^{-1}$ ) characterized by $\mathrm{CO}_{2}$ assimilation by plants, as reflected in the diurnal pattern of photosynthetic activity following insolation. During the month of August, the balance between assimilation and respiration shifted increasingly towards respiration, which correlated strongly with declining insolation and the first occurrence of darkness at night (on 23 August). During September the decreasing photosynthetic activity, together with the absence of snow, but with air and soil temperatures above freezing, led to 
prevalentecosystemrespiration and positive $\mathrm{CO}_{2}$ fluxes over a 3- to 4-week period (Fig. 2).

These positive $\mathrm{CO}_{2}$ fluxes continued until the first severe frost (25 September 2008) and/or the first full snow coverage (end of October 2008) limited any further biological activity. During the snow-covered (winter) period October to May, the processes forcing $\mathrm{CO}_{2}$ accumulation and $\mathrm{CO}_{2}$ release counterbalance each other, resulting in very low flux rates of $\pm 0.1 \mathrm{~g} \mathrm{C} \mathrm{m}^{-2} \mathrm{day}^{-1}$. However, a discernable period with small but persistent fluxes from the snow pack to the atmosphere lasted approximately until January 2009. In the following period, considerable $\mathrm{CO}_{2}$ exchange events (accumulation into the snow pack or release into the atmospheric boundary layer) of up to $\pm 2 \mathrm{~g} \mathrm{C} \mathrm{m}^{-2}$ within a few days were recorded (Sects. 3.2 and 4.1).

\subsection{Snow-atmosphere exchange of $\mathrm{CO}_{2}$}

As evident from Fig. 2, a number of significant $\mathrm{CO}_{2}$ exchange events between the snow pack and the atmosphere were recorded during winter and spring, both as positive $\mathrm{CO}_{2}$ release into the atmosphere and negative $\mathrm{CO}_{2}$ accumulation into the snow. Two of these episodes are documented in detail:

Figure 3 presents an episode of strong $\mathrm{CO}_{2}$ emissions which occurred during mesoscale pressure and air mass changes in March 2009 from a $1.2 \mathrm{~m}$ thick snow pack. Following the arrival of a warm front on 16 March, the atmospheric air pressure rapidly decreased by $22 \mathrm{hPa}$ (Fig. 3a), which coincided with a sudden increase of the wind speed (from less than $2 \mathrm{~m} \mathrm{~s}^{-1}$ to up to $8 \mathrm{~m} \mathrm{~s}^{-1}$ ), a change in wind direction from east to south (Fig. 3b, c), and an increase in air temperature from $-25^{\circ} \mathrm{C}$ to $-10^{\circ} \mathrm{C}$. Under such conditions (sharp drop of air pressure and high wind speed), a significant $\mathrm{CO}_{2}$ release from the snow pack (positive sign, upward flux) was observed until the next air mass change occurred during the ongoing passage of a warm front on 17 March. The wind direction changed from east to northwest and the wind speed increased to more than $8 \mathrm{~m} \mathrm{~s}^{-1}$ about 1.5 day. While the atmospheric $\mathrm{CO}_{2}$ concentration increased slightly, the $\mathrm{CO}_{2}$ release intensified to high rates of +40 to $+50 \mathrm{mg} \mathrm{C} \mathrm{m}^{-2} 30 \mathrm{~min}^{-1}$ for approximately 1 day. After that, the $\mathrm{CO}_{2}$ release rates displayed a strong decline although the wind speed remained high. The emission event terminated with the passage of a next cold front on 19 March, which was accompanied by a strong decrease of the wind speed and a drop in air temperature down to $-26^{\circ} \mathrm{C}$.

An event with strongly negative $\mathrm{CO}_{2}$ fluxes (i.e., uptake) occurred in spring 2008 during a distinct pressure and air mass change between 14 and 24 April (Fig. 4). As in the previous case, a cold front passed on 16 April resulting in a sharp drop in air pressure of $38 \mathrm{hPa}$, and in conjunction with high wind speeds $\left(10 \mathrm{~m} \mathrm{~s}^{-1}\right)$, coincided with a measured peak of $\mathrm{CO}_{2}$ release from the $1 \mathrm{~m}$ thick snow pack. In this case, the strong winds persisted for 7 days until 23 April, and different from the emission event in 2009, the air pressure increased continuously from 990 to $1019 \mathrm{hPa}$ while the $\mathrm{CO}_{2}$ release from the snow decreased. Around 20 April, the $\mathrm{CO}_{2}$ emission was replaced by a strong downward-directed $\mathrm{CO}_{2}$ flux (up to $-50 \mathrm{mg} \mathrm{C} \mathrm{m}^{-2} 30 \mathrm{~min}^{-1}$ ). This period of a significant downward-directed $\mathrm{CO}_{2}$ fluxes terminated on 23 April after the wind calmed down and the wind direction changed from northwest to southeast. A similar strong uptake event occurred between 15 and 19 June 2008 during snowmelt (not shown), where snow-free areas already occurred in the eddy footprint area (see Fig. 13 in Westermann et al., 2009a). All three events have a pronounced impact on the yearly balance, with total absolute contributions of 2 to $3 \mathrm{~g} \mathrm{C} \mathrm{m}^{-2}$ per event (Fig. 2). While we cannot provide a comprehensive explanation of these fluxes based on our measurements (see Sect. 4.1 for a discussion of possible mechanisms), we note characteristic patterns in the meteorological forcing during these three events:

- Episodes with high fluxes exclusively occurred during periods of high wind speeds ( $>6$ to $10 \mathrm{~m} \mathrm{~s}^{-1}$ ). On the other hand, many more periods with such wind speeds occurred without associated high $\mathrm{CO}_{2}$ fluxes.

- All events were accompanied by marked changes of the atmospheric pressure in the period before and during the actual event. However, there is no clear relationship between pressure variation and the actual flux (Figs. 3, 4).

- While the net radiation was negative during the release event in March, it was positive for the uptake events in April and June (Fig. 1). Hence, melting of the snow did not occur for the release events, but it cannot be excluded for the April uptake event, although the air temperature remained well below $0^{\circ} \mathrm{C}$. For the June event, the snow pack was in the final stages of melting and partly saturated by meltwater (Westermann et al., 2009a).

While the snow acts as a storage layer that buffers the $\mathrm{CO}_{2}$ exchange between soil and atmosphere, the strong exchange events suggest that the actual gas exchange, i.e., the emptying or potential refilling of the storage, is at least partly forced by mesoscale meteorological factors on timescales of hours to days.

\section{Discussion}

\subsection{The role of winter $\mathrm{CO}_{2}$ fluxes}

During the winter season, a small but sustained $\mathrm{CO}_{2}$ from the snow occurs most of the time at the Svalbard site, which has been also found in other Arctic, sub-Arctic, and high mountain areas (e.g., Björkmann et al., 2010b; Euskirchen et al., 
Bayelva, Svalbard, $79^{\circ} \mathrm{N}$

$2008 / 2009$
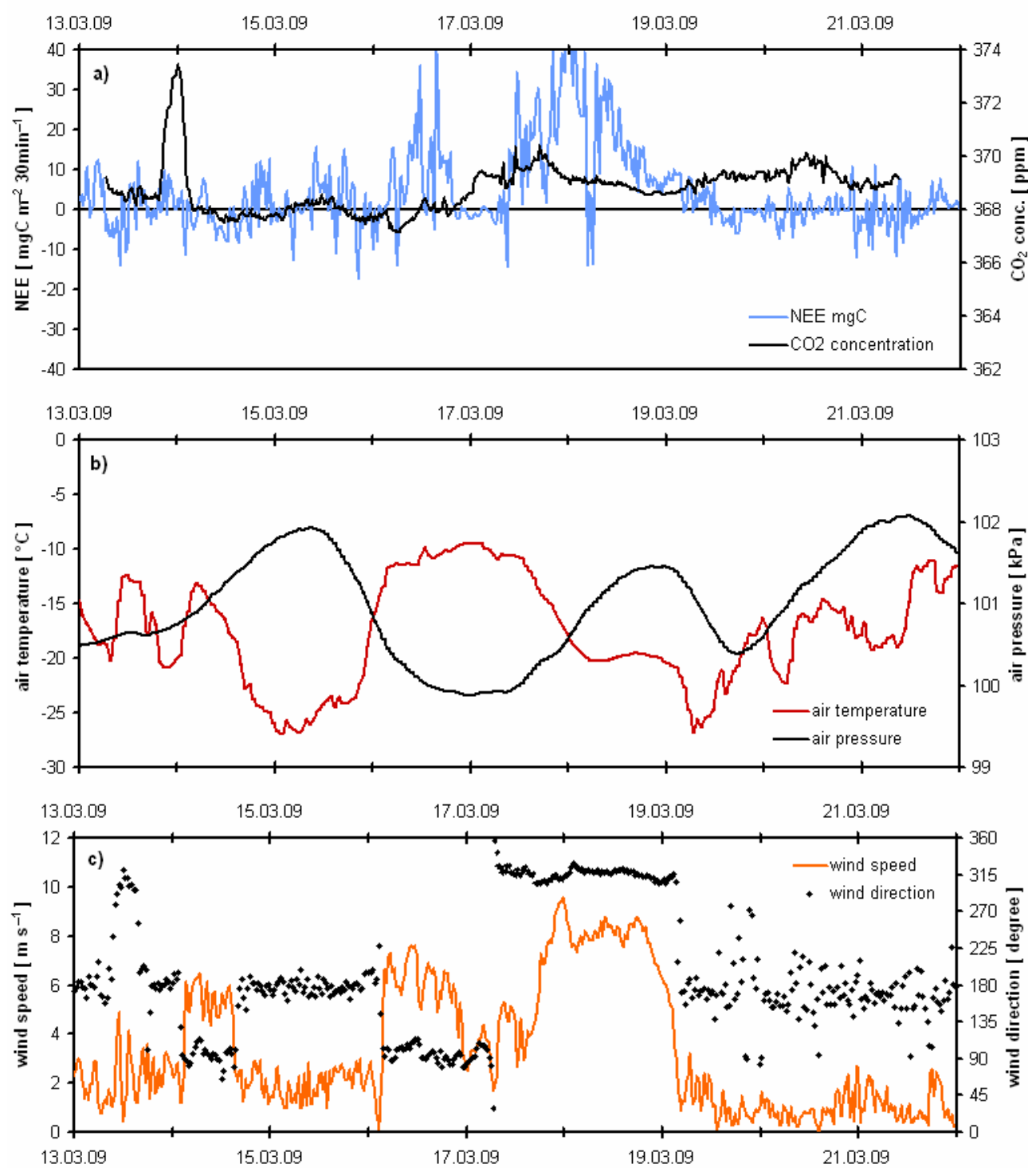

Figure 3. Gas exchange 13 to 21 March 2009, full snow cover (1.2 m height); Bayelva Observation Site, Svalbard. In panel (a), the blue line shows net ecosystem exchange (NEE) of carbon dioxide $\left[\mathrm{mg} \mathrm{C} \mathrm{m}^{-2} 30 \mathrm{~min}^{-1}\right]$ and the black line shows atmospheric $\mathrm{CO}_{2}$ concentration [ppm], LI-7500 gas analyzer; in panel (b), the red line shows air temperature at $2 \mathrm{~m}$ a.g.1. $\left[{ }^{\circ} \mathrm{C}\right]$ and black line shows Ny-Ålesund station air pressure $[\mathrm{kPa}]$; in panel $(\mathbf{c})$, the orange line shows wind speed $\left[\mathrm{m} \mathrm{s}^{-1}\right]$ and black dots show wind direction $\left[{ }^{\circ}\right]$, ultrasonic anemometer.

2012; McDowell et al., 2000). While our measurements confirm and underline these findings, they also suggest that the biotic and abiotic processes involved in the $\mathrm{CO}_{2}$ exchange through the snow pack are rather complex.

At the Svalbard site, the period of small but sustained diffusive emissions through the snow pack lasts only until about January (when the snow pack is already fully developed), while positive and negative fluxes occur between January and the snow melt in June (Fig. 2). In contrast, sustained emissions occurred throughout the entire snow-covered period at the sub-Arctic Alaskan site (Euskirchen et al., 2012).
A straightforward interpretation could be that soil respiration ceased or was at least strongly reduced around mid-winter at the Svalbard site, either because the microbial activity in the active layer terminated or because the carbon stock available for microbial decomposition was depleted. At the more organic-rich Alaskan site, respiration continued throughout the entire winter season.

Between January and June, our measurements show fluxes in both directions of generally low magnitude, though interrupted by short periods of intense exchange, at a magnitude comparable to the summer fluxes (Sect. 3.2). These 
Bayelva, Svalbard, $79^{\circ} \mathrm{N}$

$2008 / 2009$
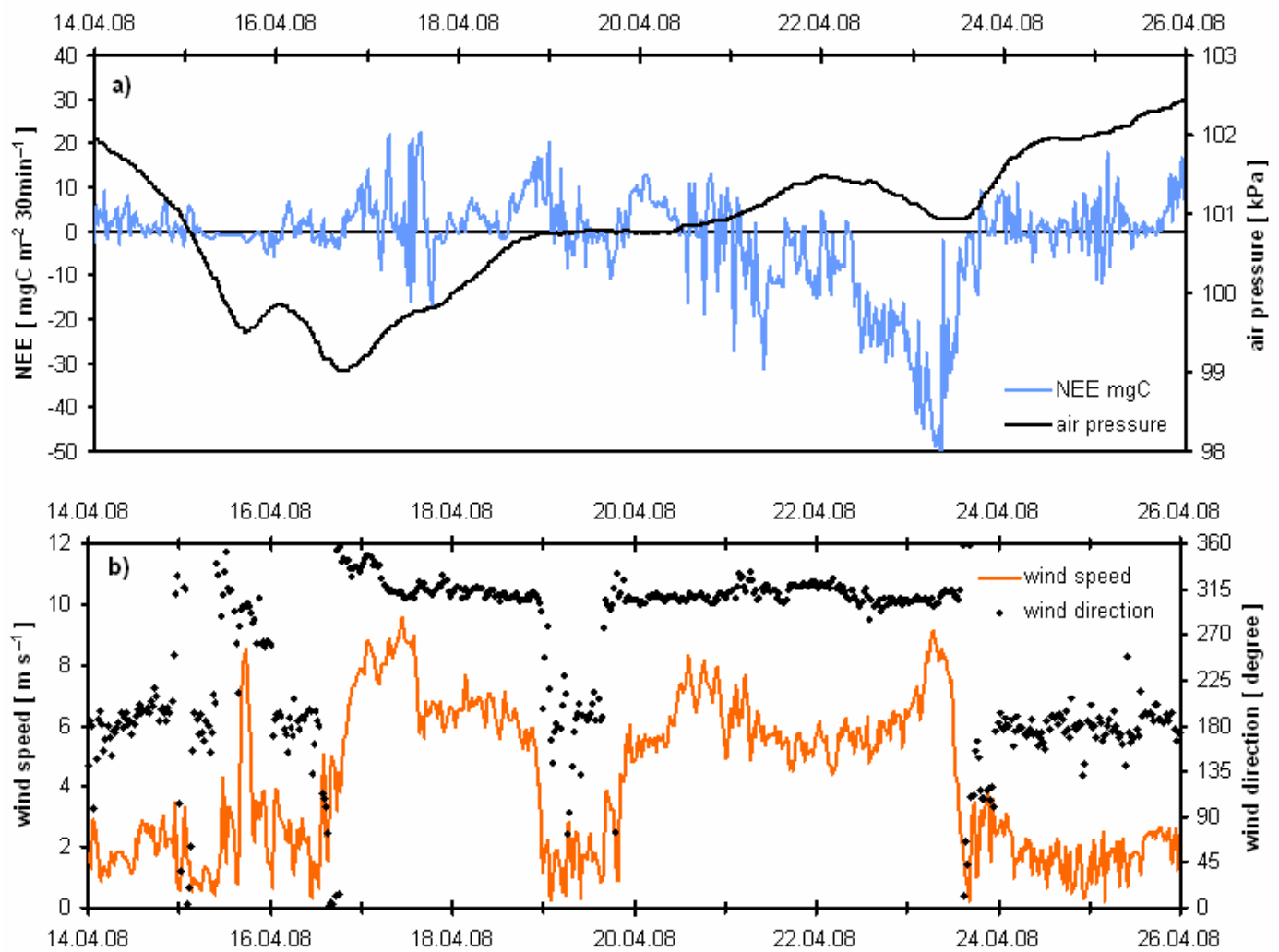

Figure 4. Gas exchange 14 to 25 April 2008, full snow cover (1.1 m height); Bayelva Observation Site, Svalbard. In panel (a), the blue line shows net ecosystem exchange (NEE) of carbon dioxide $\left[\mathrm{mg} \mathrm{C} \mathrm{m}^{-2} 30 \mathrm{~min}^{-1}\right.$ ] and the black line shows Ny-Ålesund station air pressure $[\mathrm{kPa}]$; in panel (b), the orange line shows wind speed $\left[\mathrm{m} \mathrm{s}^{-1}\right]$ and black dots show wind direction $\left[^{\circ}\right]$.

events did not exclusively occur during periods with high wind speed. It is also possible that the changes in atmospheric pressure recorded shortly prior and during strong flux events resulted in an additional pumping effect, which led to mixing of gas within the snow pack and a release/uptake at the snow surface. Such pressure effects have been observed for other ecosystems, like peatlands and methane emissions in sub-tropical Japan (Tokida et al., 2007) or over a grass steppe $\left(\mathrm{CO}_{2}\right)$ in southeast Spain (Rey et al., 2012; SánchezCañete et al., 2013).

These mesoscale turbulence-driven "wind and pressure pumping" events therefore suggest a large convective gas transport into, within, or out of the snow pack as modeled by Bowling and Massman (2011), or earlier by Björkmann et al. (2010b), Seok et al. (2009), Massman (2006), and Massman and Frank (2006), none of whom had any direct atmospheric trace gas flux measurements from above the snow surface that they could use to observe these severe exchange events.

Both effects can explain the strong $\mathrm{CO}_{2}$ emission event in March 2009 (Sect. 3.2) if one assumes that wind pumping and/or pressure changes triggered the release of $\mathrm{CO}_{2}$ stored in the snow pack from autumn and early winter soil respiration. During the $\mathrm{CO}_{2}$ uptake event in April 2009, wind and pressure pumping and ventilation of the snow pack may have played a role as well, but a full explanation would require prescribing a mechanism to store the corresponding amounts of $\mathrm{CO}_{2}$ within the snow pack. If such a mechanism exists, it is likely that it would not be detectable in studies at more southerly sites where ongoing soil respiration constantly recharges the snow pack with $\mathrm{CO}_{2}$. Over sea ice, negative fluxes of generally lower magnitude have been recorded in winter (Nomura et al., 2010), which is related to changes in the partial $\mathrm{CO}_{2}$ pressure of the brine. While sea salt is present in the snow pack in the study area around $\mathrm{Ny}$ Ålesund (Domine et al., 2004), any connection to $\mathrm{CO}_{2}$ fluxes is purely speculative. Another possibility could be an uptake of $\mathrm{CO}_{2}$ by the meltwater produced (as recorded in ice cores, Jinho et al., 2008), which could explain $\mathrm{CO}_{2}$ fluxes into the snow pack, but can most likely not explain the magnitude of the fluxes recorded in this study. During the uptake event in June (Sect. 3.2), the footprint of the eddy covariance system was characterized by melting snow patches (Westermann et al., 2009a). Hence, the measured flux values must be seen 
as a mix of strongly different flux sources, i.e., snow-free areas with possibly strong photosynthetic activity and snow patches/melt water ponds with $\mathrm{CO}_{2}$ emission or uptake determined by abiotic factors, which prevents a complete picture at this point.

In conclusion, it is not possible to provide a coherent interpretation of the strong winter flux events from the available data set. Therefore, some uncertainty remains whether the strong flux events are a countable contribution to the annual NEE. The eddy covariance technique is associated with a number of uncertainties (e.g., Aubinet et al., 2012) and additional error sources may exist for measurements in the Arctic (Lüers and Bareiss, 2010, 2011, Appendix A). Since this aspect constitutes a major source of uncertainty for the annual NEE budget, it deserves attention in future studies, for example, by measurement of $\mathrm{CO}_{2}$ gradients above and within the snow pack and in the active layer.

\subsection{NEE at the Bayelva site in a circumpolar perspective}

An annual cumulative NEE of close to zero was recorded in this study, which is in agreement with the low soil carbon contents reported from the study site (Boike et al., 2008). Despite the uncertainties in the winter fluxes, we are confident that this study can capture the magnitude and the seasonal dynamics of NEE at the high Arctic study site, which is supported by previous studies at the study site covering comparatively short time periods. In 1995, Lloyd $(2001 \mathrm{a}, \mathrm{b})$ reported a net $\mathrm{CO}_{2}$ source during late snowmelt $\left(+0.3 \mathrm{~g} \mathrm{C} \mathrm{m}^{-2} \mathrm{day}^{-1}\right)$ changing to a net $\mathrm{CO}_{2}$ assimilation rate of $-0.4 \mathrm{~g} \mathrm{C} \mathrm{m}^{-2} \mathrm{day}^{-1}$ at summer, and then returning to a net $\mathrm{CO}_{2}$ release rate of $+0.1 \mathrm{~g} \mathrm{C} \mathrm{m}^{-2}$ day $^{-1}$ in the early autumn. While the snowmelt and summer rates recorded in this study are in excellent agreement, our $\mathrm{CO}_{2}$ release rates of $+0.5 \mathrm{~g} \mathrm{C} \mathrm{m}^{-2} \mathrm{day}^{-1}$ observed in September 2008 are approximately 5 times greater, which could be due to temporal and/or spatial variability of the autumn respiration fluxes. Chamber measurements by Uchida et al. (2009) recorded a $\mathrm{CO}_{2}$ release of $+0.3 \mathrm{~g} \mathrm{C} \mathrm{m}^{-2} \mathrm{day}^{-1}$ at a nearby site from the thawing soil following complete snowmelt in 2001, but no such effect occurred during our campaign in 2008-2009.

Both summer and winter data have been collected from other Svalbard sites (Adventdalen, Longyearbyen) using air sampling (in the snow) and closed chamber methods (Björkmann et al., 2010a). They reported winter emissions of about 1 to $2 \%$ of the total annual emissions, which ranged from +1.1 to $+3.3 \mathrm{~g} \mathrm{C} \mathrm{m}^{-2} \mathrm{yr}^{-1}$. The differences between these budgets and eddy-covariance-derived NEE estimate of this study could be explained by interannual and site-specific variation, and the differences between the (non-comparable) experimental techniques and models employed (Merbold et al., 2012). An example are the strong flux events during periods of high wind speeds recorded by eddy covari- ance (Sects. 3.2, 4.1), which are most likely not detectable in closed chamber measurements (zero wind speed inside the chamber, chambers buried by drifting snow).

Compared to more productive ecosystems in the Arctic (Shaver et al., 2007), the Bayelva site features relatively low daily fluxes of $\mathrm{CO}_{2}$, both during summer assimilation and autumn respiration. A much larger carbon exchange between June and August (NEE of $-119 \mathrm{~g} \mathrm{C} \mathrm{m}^{-2}$ ) is reported from Samoylov Island in NE Siberia which is characterized by high organic soil content as well as numerous ponds and lakes (Kutzbach et al., 2007). During autumn (September) these water bodies account for between $74 \%$ and $81 \%$ of the calculated net landscape-scale $\mathrm{CO}_{2}$ emissions at the Siberian Samoylov Island (Abnizova et al., 2012). At Imnavait Creek in Alaska, a NEE between -51 and $-95 \mathrm{~g} \mathrm{C} \mathrm{m}^{-2}$ from different ecosystem types and years is reported for June to August (Euskirchen et al., 2012). Nevertheless, the $\mathrm{CO}_{2}$ uptake of $-12 \mathrm{~g} \mathrm{C} \mathrm{m}^{-2}$ during the summer period at the Bayelva site (June, July, August) is remarkably large for such a sparsely vegetated site within the polar climate zone. However, the daily carbon uptake during the summer of 2008 was slightly lower than at the comparable Zackenberg site in northeast Greenland ( -0.5 to $-1.4 \mathrm{~g} \mathrm{C} \mathrm{m}^{-2}$ day $^{-1}$, Groendahl et al., 2007).

The release of $+7 \mathrm{~g} \mathrm{C} \mathrm{m}^{-2}$ during the autumn (September, October and November) respiration period is significant for the high Arctic carbon balance. During fully snow-covered winter conditions, the carbon balance appears to be more or less in balance (with the exception of a few, but considerable $\mathrm{CO}_{2}$ exchange events as discussed earlier).

\section{Summary and conclusion}

The annual carbon balance at this permafrost study site on Spitsbergen is close to zero, displaying a balance between the short summer carbon uptake and the long autumn and winter carbon release. This study has identified four major carbon exchange seasons, each of which makes a significant contribution to the carbon cycle at this high Arctic site:

1. spring (May-June, snow ablation) - the total net flux is a carbon uptake of about $-1.5 \mathrm{~g} \mathrm{C} \mathrm{m}^{-2}$. In this period, gas exchange through the snow pack coincides with the beginning of biological activity on snow-free patches.

2. summer (July-August, snow-free) - the measured cumulative NEE signal shows an accumulated carbon uptake of $-10 \mathrm{~g} \mathrm{C} \mathrm{m}^{-2}$. The gas exchange between soil, vegetation, and the atmosphere is dominated by $\mathrm{CO}_{2}$ assimilation by plants.

3. autumn (September-October, snow-free/partial snow coverage) - the measured cumulative NEE signal shows a release of carbon of about $+4.5 \mathrm{~g} \mathrm{C} \mathrm{m}^{-2}$. The $\mathrm{CO}_{2}$ exchange predominantly occurs due to $\mathrm{CO}_{2}$ respiration by microorganisms and plant roots. 
4. winter (November-April, full snow coverage) - a net release of carbon between $+6 \mathrm{~g} \mathrm{C} \mathrm{m}^{-2}$ and $+7 \mathrm{~g} \mathrm{C} \mathrm{m}^{-2}$ (from 0.3 and $0.5 \mathrm{~g} \mathrm{C} \mathrm{m}^{-2}$ for January and February to 2.1 and $1.8 \mathrm{~g} \mathrm{C} \mathrm{m}^{-2}$ for November and December) was measured. The gas exchange between soil, snow, and the atmosphere are most likely derived from soil respiration, but the release is mediated by the snow cover and mesoscale wind and pressure forcings.
The results of this 12-month study emphasize the significance of small winter carbon fluxes for the total annual carbon budget of Arctic ecosystems. The measurements suggest that approximately two-thirds of the summertime $\mathrm{CO}_{2}$ uptake is compensated by the wintertime $\mathrm{CO}_{2}$ release, while one-third occurs during the autumn respiration. The snow cover plays an important role in storing and releasing $\mathrm{CO}_{2}$ through atmospheric forcing. The state (source or sink) of an Arctic ecosystem can therefore only be addressed by continued, year-round and multiyear measurements of trace gas fluxes and atmospheric circulation and exchange patterns. 


\section{Appendix A: LI-7500 instrument surface heating correction (Burba correction)}

The heat generated by the sensor body of an LI-7500 openpath gas analyzer (LI-COR Biosciences Inc.) is a potential error source of eddy covariance measurements (Lafleur and Humphreys, 2007). Such artificial heating may result in convection within the sampling volume (the infrared pathway) and thus influence the WPL (Webb-Pearman-Leuning) correction for density fluctuations (Webb et al., 1980). At the current state of knowledge, it remains uncertain how this influence can be avoided or corrected (Grelle and Burba, 2007; Burba et al., 2008; Järvi et al., 2009; Burba and Anderson, 2010; Burba, 2013; Oechel et al., 2014). In this study, the sensor head was tilted to one side by $45^{\circ}$ so that convective plumes generated by artificial heating would rise away from the sensor's infrared pathway (Foken, 2008). This minimizes (and may even eliminate) any possible error due to heat generated by the sensor. The correction suggested by Burba et al. (2008) and Burba (2013) that was not applied is documented in the following. We attempted the only method suitable for correcting our data set which was collected without available in-path rapid temperature measurements (method 4).

According to Burba et al. (2008), the total sensible heat flux $Q_{\mathrm{H}}^{\text {cor }}$ for the WPL term is computed by adding estimated sensible heat fluxes $(S)$ from key instrument surfaces around the open path, i.e., from the bottom window $\left(S^{\text {bot }}\right)$, the top window $\left(S^{\text {top }}\right)$, and the spar $\left(S^{\mathrm{spar}}\right)$, to the ambient sensible heat flux $\left(\rho C_{\mathrm{p}} \overline{w^{\prime} T^{\prime}}\right)$ :

$Q_{\mathrm{H}}^{\mathrm{cor}}=\rho C_{\mathrm{p}} \overline{w^{\prime} T^{\prime}}+S^{\mathrm{bot}}+S^{\mathrm{top}}+0.15 S^{\mathrm{spar}}$.

To obtain the additional sensible energy $S$ emitted from these three key instrument surfaces, Burba et al. (2008) used the conductivity formulation by Nobel (1983) where the thermal conductivity coefficient of air $\left(k^{\text {air }}\right.$, in $\left.\mathrm{W}^{-1} \mathrm{~K}^{-1}\right)$ is multiplied by the quotient of $T_{\mathrm{S}}$, which is the mean surface temperature of the bottom window $\left(T_{\mathrm{s}}^{\mathrm{bot}}\right)$, the top window $\left(T_{\mathrm{s}}^{\text {top }}\right)$, and the spar $\left(T_{\mathrm{s}}^{\mathrm{spar}}\right)$ minus the ambient air temperature $\left(T_{\mathrm{a}}\right)$ in Kelvin, divided by the geometrical parameters describing the sphere of the affected boundary layer between the bottom and top window and spar, and the size and shape of the instrument's body parts (see Table 1 in Burba et al., 2008).

The required values for $T_{\mathrm{S}}$ were estimated by Burba et al. (2008) through multiple regressions with the key weather variables of air temperature $\left(T_{\mathrm{a}}\right)$, radiation, and wind speed (see Table 2 and Fig. 3 in Burba et al., 2008).
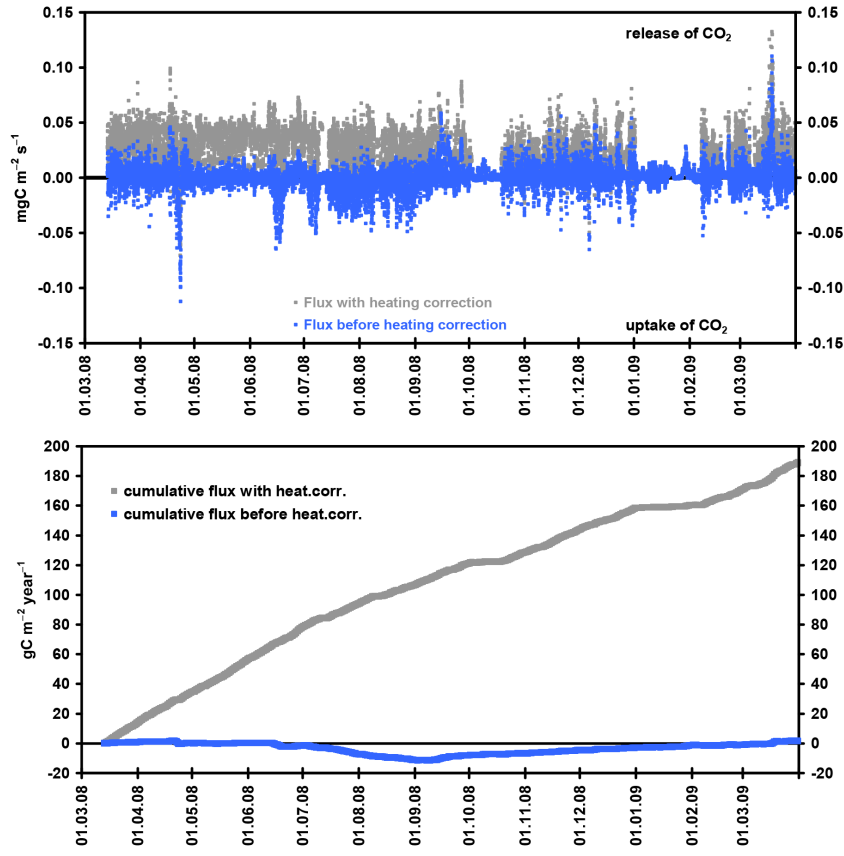

Figure A1. Original (kept) carbon flux values (blue) prior to correction for heat produced by the LI-7500 gas sensor, and (discarded) carbon flux values following heat correction (gray). Top panel: time series of $30 \mathrm{~min}$ flux values; bottom panel: accumulated fluxes between March 2008 and March 2009, Bayelva Eddy Flux Station, Svalbard $\left(79^{\circ} \mathrm{N}\right)$.

If the net radiation $\left(R_{\text {net }}\right)$ is greater than zero (daytime) the relevant relationships are

$T_{\mathrm{s}}^{\mathrm{bot}}=0.944 \cdot T_{\mathrm{a}}+2.57$,

$T_{\mathrm{s}}^{\text {top }}=1.005 \cdot T_{\mathrm{a}}+0.24$,

$T_{\mathrm{s}}^{\text {spar }}=1.01 \cdot T_{\mathrm{a}}+0.36$,

and if $R_{\text {net }}$ is less than zero (night time),

$T_{\mathrm{s}}^{\mathrm{bot}}=0.833 \cdot T_{\mathrm{a}}+2.17$,

$T_{\mathrm{s}}^{\text {top }}=1.008 \cdot T_{\mathrm{a}}-0.41$,

$T_{\mathrm{s}}^{\mathrm{spar}}=1.01 \cdot T_{\mathrm{a}}-0.17$.

Using these relationships, we obtained net ecosystem exchange (NEE) values (Fig. A1) that amounted to an unrealistically high annual carbon budget of around $+190 \mathrm{~g} \mathrm{C} \mathrm{m}^{-2} \mathrm{yr}^{-1}$ compared to around zero $\mathrm{g} \mathrm{C} \mathrm{m}^{-2} \mathrm{yr}^{-1}$ without the correction, which is more plausible considering the low carbon content in the soils at the study site (Boike et al., 2008). The high annual NEE values are most likely related to a constant positive offset (produced by the correction equations) of around $0.03 \mathrm{mg} \mathrm{C} \mathrm{m}^{-2} \mathrm{~s}^{-1}$ added to each of the NEE flux values (see Table 4 in Burba et al., 2008 and also Euskirchen et al., 2012). However, if the $\mathrm{CO}_{2}$ fluxes are very low and fluctuate within a narrow range close to zero as in 
our case, this bias, induced by only $15 \mathrm{~J} \mathrm{~s}^{-1}$ of heating power, resulted in an unrealistic addition of around 10 to $15 \mathrm{~W} \mathrm{~m}^{-2}$ (sum of $S^{\text {bot }}, S^{\text {top }}$, and $S^{\text {spar }}$ ) to the standard WPL correction term for a vertically oriented LI-7500 sensor head, irrespective of the wind speed and air temperature. Consequently, the flux direction was changed for many values which resulted in a large positive bias for the total carbon budget (Fig. A1).
On the one hand, it is possible that the correction is not applicable for a tilted sensor, as described by Oechel et al. (2014). On the other hand, our results suggest that caution is warranted when applying the correction for low $\mathrm{CO}_{2}$ fluxes in the range of the heat correction offset. As outlined in Sect. 2.2, we therefore chose not to apply the correction to the data set presented in this study. 
Acknowledgements. The authors would like to thank all participants from the French-German Arctic Research Base led by the Alfred Wegener Institute for Polar and Marine Research (AWI), and from the Institut polaire français - Paul Émile Victor (IPEV), for their efforts to ensure the success of measurement-collection operations at the Bayelva observation site. We also appreciated the logistics support provided by the staff of the Kingsbay Company on Ny-Ålesund. We are very grateful to Thomas Foken, Head of the Micrometeorology Department at the University of Bayreuth, for the major support and counsel that he provided. This work was supported through a grant by the European Union FP7ENVIRONMENT project PAGE21 under contract no. GA282700.

Edited by: P. Stoy

\section{References}

Abnizova, A., Siemens, J., Langer, M., and Boike, J.: Small ponds with major impact: The relevance of ponds and lakes in permafrost landscapes to carbon dioxide emissions, Global Biogeochem. Cy., 26, GB2041, doi:10.1029/2011gb004237, 2012.

Aubinet, M., Vesala, T., and Papale, D. (Eds.): Eddy Covariance A Practical Guide to Measurement and Data Analysis, Series: Springer Atmospheric Sciences, Springer, Heidelberg, p. 438, 2012.

Aurela, M., Laurila, T., and Tuovinen, J. P.: The timing of snow melt controls the annual $\mathrm{CO}_{2}$ balance in a subarctic fen, Geophys. Res. Lett., 31, L16119, doi:10.1029/2004GL020315, 2004.

Björkman, M. P., Morgner, E., Björk, R. G., Cooper, E. J., Elberling, B., and Klemedtsson, L.: A comparison of annual and seasonal carbon dioxide effluxes between sub-Arctic Sweden and HighArctic Svalbard, Polar Res., 29, 75-84, 2010a.

Björkman, M. P., Morgner, E., Cooper, E. J., Elberling, B., Klemedtsson, L., and Björk R. G.: Winter carbon dioxide effluxes from Arctic ecosystems: An overview and comparison of methodologies, Global Biogeochem. Cy., 24, GB3010, doi:10.1029/2009GB003667, 2010b.

Boike, J., Roth, K., and Ippisch, O.: Seasonal snow cover on frozen ground: Energy balance calculations of a permafrost site near Ny-Ålesund, Spitsbergen, J. Geophys. Res., 108, 8163, doi:10.1029/2001JD000939, 2003.

Boike, J., Ippisch, O., Overduin, P., Hagedorn, B., and Roth, K.: Water, heat and solute dynamics of a mud boil, Spitsbergen, Geomorphology, 95, 61-73, 2008.

Bowling D. R. and Massman, W. J.: Persistent wind-induced enhancement of diffusive $\mathrm{CO}_{2}$ transport in a mountain forest snowpack, J. Geophys. Res., 116, 1-15, doi:10.1029/2011JG001722, 2011.

Burba, G.: Eddy Covariance Method for Scientific, Industrial, Agricultural, and Regulatory Applications: A Field Book on Measuring Ecosystem Gas Exchange and Areal Emission Rates, LICOR Biosciences Inc., Lincoln, NE, USA, 331 pp., 2013.

Burba, G. and Anderson, D.: A brief practical guide to eddy covariance flux measurements, Li-COR Biosciences Inc., Lincoln, NE, USA, 2010.

Burba, G., McDermitt, D. K., Grelle, A., Anderson, D., and Xu, L.: Addressing the influence of instrument surface heat exchange on the measurements of $\mathrm{CO}_{2}$ flux from open-path gas analyzers, Glob. Change Biol., 14, 1854-1876, 2008.
Chapin III, F. S., Miller, P. C., Billings, W. D., and Coyne, P. I.: Carbon and nutrient budgets and their control in coastal tundra, in: An arctic ecosystem: The coastal tundra at Barrow, Alaska, edited by: Brown, J., Miller, P. C., Tieszen, L. L., and Bunnell, F. L., Dowden, Hutchinson and Ross Inc., Stroudsburg/Pennsylvania, 458-482, 1980.

Corradi, C., Kolle, O., Walter, K., Zimov, S. A., and Schulze, E. D.: Carbon dioxide and methane exchange of a north-east Siberian tussock tundra, Glob. Change Biol., 11, 1910-1925, 2005.

Domine, F., Sparapani, R., Ianniello, A., and Beine, H. J.: The origin of sea salt in snow on Arctic sea ice and in coastal regions, Atmos. Chem. Phys., 4, 2259-2271, doi:10.5194/acp-4-2259-2004, 2004.

Eigenmann, R., Kalthoff, N., Foken, T., Dorninger, M., Kohler, M., Legain, D., Pigeon, G., Piguet, B., Schüttemeyer, D., and Traulle, O.: Surface energy balance and turbulence network during COPS, Q. J. Roy. Meteor. Soc., 137, 57-69, 2011.

Elberling, B. and Brandt, K. K.: Uncoupling of microbial $\mathrm{CO}_{2}$ production and $\mathrm{CO}_{2}$ release in frozen soil and its implications for field studies of arctic C cycling, Soil Biol. Biochem., 35, 263-272, 2003.

Euskirchen, E. S., Bret-Harte, M. S., Scott, G. J., Edgar, C., and Shaver, G. R.: Seasonal patterns of carbon dioxide and water fluxes in three representative tundra ecosystems in northern Alaska, Ecosphere, 3, 1-19, 2012.

Fahnestock, J. T., Jones, M. H., Brooks, P. D., Walker, D. A., and Welker, J. M.: Winter and spring $\mathrm{CO}_{2}$ Efflux from Tundra Communities of Northern Alaska, J. Geophys. Res., 103, 29023-29027, 1998.

Fahnestock, J. T., Jones, M. H., and Welker, J. M.: Wintertime $\mathrm{CO}_{2}$ efflux from arctic soils: implications for annual carbon budgets, Global Biogeochem. Cy., 13, 775-779, 1999.

Falge, E., Baldocchi, D., Olson, R., Anthoni, P., Aubinet, M., Bernhofer, C., Burba, G., Ceulemans, R., Clement, R., Dolman, H., Granier, A., Gross, P., Grunwald, T., Hollinger, D., Jensen, N. O., Katul, G., Keronen, P., Kowalski, A., Lai, C. T., Law, B. E., Meyers, T., Moncrieff, H., Moors, E., Munger, J. W., Pilegaard, K., Rannik, U., Rebmann, C., Suyker, A., Tenhunen, J., Tu, K., Verma, S., Vesala, T., Wilson, K., and Wofsy, S.: Gap filling strategies for defensible annual sums of net ecosystem exchange, Agr. Forest Meteorol., 107, 43-69, 2001.

Finnigan, J., Clement, R., Malhi, Y., Leuning, R., and Cleugh, H. A.: A reevaluation of long-term flux measurement techniques. Part I: Averaging and coordinate rotation, Bound-Lay Meteorol. 107, 1-48, 2003.

Foken, T.: Micrometeorology, Springer, Heidelberg, 2008.

Foken, T. and Wichura, B.: Tools for quality assessment of surfacebased flux measurements, Agr. Forest Meteorol., 78, 83-105, 1996.

Foken, T., Göckede, M., Mauder, M., Mahrt, L., Amiro, B. D., and Munger, J. W.: Post-field data quality control, in: Handbook of Micrometeorology: A Guide for Surface Flux Measurement and Analysis, edited by: Lee, X., Massman, W., Law, B. E., Kluwer, Dordrecht, 181-208, 2004.

Foken, T., Leuning, R., Oncley, S. P., Mauder, M., and Aubinet, M.: Corrections and data quality, in: Eddy Covariance: A Practical Guide to Measurement and Data Analysis, edited by: Aubinet, M., Vesala, T., and Papale, D., Springer, Berlin, Heidelberg, 85-131, 2012. 
Graven, H., Keeling, R., Piper, S., Patra, P., Stephens, B., Wofsy, S., Welp, L., Sweeney, C., Tans, P., Kelley, J., Daube, B. C., Kort, E. A., Santoni, G. W., and Bent, J. D.: Enhanced seasonal exchange of $\mathrm{CO}_{2}$ by northern ecosystems since 1960, Science, 341, 1085-1089, 2013.

Grelle, A. and Burba, G.: Fine-wire thermometer to correct $\mathrm{CO}_{2}$ fluxes by open-path analyzers for artificial density fluctuations, Agr. Forest Meteorol., 147, 48-57, 2007.

Groendahl, L., Friborg, T., and Soegaard, H.: Temperature and snow-melt controls on interannual variability in carbon exchange in the high Arctic, Theor. Appl. Climatol., 88, 111-125, 2007.

Grogan, P. and Chapin III, F. S.: Arctic soil respiration: Effects of climate and vegetation depend on season, Ecosystems, 2, 451-459, 1999.

Hanssen-Bauer, I. and Førland, E. J.: Long-term trends in precipitation and temperature in the Norwegian Arctic: can they be explained by changes in atmospheric circulation patterns?, Clim. Res., 10, 143-153, 1998.

Heikkinen, J. E. P., Virtanen, T., Huttunen, J. T., Elsakov, V., and Martikainen, P. J.: Carbon balance in East European tundra, Global Biogeochem. Cy., 18, GB1023, doi:10.1029/2003GB002054, 2004.

Humlum, O.: Holocene permafrost aggradation in Svalbard, Geological Society London, Special Publications, 242, 119-129, doi:10.1144/GSL.SP.2005.242.01.11, 2005.

Humphreys, E. R. and Lafleur, P. M.: Does earlier snowmelt lead to greater $\mathrm{CO}_{2}$ sequestration in two low Arctic tundra ecosystems? Geophys. Res. Lett., 38, L09703, doi:10.1029/2011GL047339, 2011.

Isaksen, K., Holmlund, P., Sollid, J. L., and Harris, C.: Three Deep Alpine-Permafrost Boreholes in Svalbard and Scandinavia, Permafrost Periglac., 12, 13-25, 2001.

Isaksen, K., Sollid, J. L., Holmlund, P., and Harris, C.: Recent warming of mountain permafrost in Svalbard and Scandinavia, J. Geophys. Res., 112, F02S04, doi:10.1029/2006JF000522, 2007.

Järvi, L., Mammarella, I., Eugster, W., Ibrom, A., Siivola, E., Dellwik, E., Keronen, P., Burba, G., and Vesala, T.: Comparison of net $\mathrm{CO}_{2}$ fluxes measured with open- and closed-path infrared gas analyzers in urban complex environment, Boreal Environ. Res., 14, 499-514, 2009.

Jinho, A., Headly, M., Wahlen, M., Brook, E. J., Mayewski P. A., and Taylor, K. C.: $\mathrm{CO}_{2}$ diffusion in polar ice: observations from naturally formed $\mathrm{CO}_{2}$ spikes in the Siple Dome (Antarctica) ice, J. Glaciol., 54, 685-695, 2008

Jocher, G., Karner, F., Ritter, C., Neuber, R., Dethloff, K., Obleitner, F., Reuder, J., and Foken, T.: The near-surface small-scale spatial and temporal variability of sensible and latent heat exchange in the Svalbard region: a case study, ISRN Meteorology, 357925, doi:10.5402/2012/357925, 2012.

Johansson, T., Malmer, N., Crill, P. M., Friborg, T., Åkerman, J. H., Mastepanov, M., and Christensen, T. R.: Decadal vegetation changes in a northern peatland, greenhouse gas fluxes and net radiative forcing, Glob. Change Biol., 12, 2352-2369, 2006.

Kutzbach, L., Wille, C., and Pfeiffer, E.-M.: The exchange of carbon dioxide between wet arctic tundra and the atmosphere at the Lena River Delta, Northern Siberia, Biogeosciences, 4, 869-890, doi:10.5194/bg-4-869-2007, 2007.

Kwon, H. J., Oechel, W. C., Zulueta, R. C., and Hastings, S. J.: Effects of climate variability on carbon sequestration among ad- jacent wet sedge tundra and moist tussock tundra ecosystems, J. Geophys. Res., 111, G03014, doi:10.1029/2005JG000036, 2006.

Lafleur, P. M. and Humphreys, E. R.: Spring warming and carbon dioxide exchange over low Arctic tundra in central Canada, Glob. Change Biol., 14, 740-756, 2007.

Lloyd, C. R.: On the physical controls of the carbon dioxide balance at a high Arctic site in Svalbard, Theor. Appl. Climatol., 70, 167-182, 2001a.

Lloyd, C. R.: The measurement and modelling of the carbon dioxide exchange at a high Arctic site in Svalbard, Glob. Change Biol., 7, 405-426, 2001b.

Lloyd, C. R., Harding, R. J., Friborg, T., and Aurela, R.: Surface fluxes of heat and water vapour from sites in the European Arctic, Theor. Appl. Climatol., 70, 19-33, 2001.

Lüers, J. and Bareiss, J.: The effect of misleading surface temperature estimations on the sensible heat fluxes at a high Arctic site the Arctic Turbulence Experiment 2006 on Svalbard (ARCTEX2006), Atmos. Chem. Phys., 10, 157-168, doi:10.5194/acp-10157-2010, 2010.

Lüers, J. and Bareiss, J.: Direct near-surface measurements of sensible heat fluxes in the arctic tundra applying eddy-covariance and laser scintillometry - The Arctic Turbulence Experiment 2006 on Svalbard (ARCTEX-2006), Theor. Appl. Climatol., 105, 387-402, 2011.

Lüers, J. and Bareiss, J.: Turbulent flux and meteorological measurements during ARCTEX-2006 campaign, Datasets \#811060 to \#811066, PANGAEA Data Publisher for Earth Environ. Sci., doi:10.1594/PANGAEA.811066, 2013.

Lüers, J. and Boike, J.: Time series of annual atmospheric $\mathrm{CO}_{2}$ fluxes above a high-arctic permafrost site, Svalbard (Norway), 2008-03-2009-03, PANGAEA Data Publisher for Earth and Environmental Science, doi:10.1594/PANGAEA.809507, 2013.

Lund M., Falk J. M., Friborg, T., Mbufong, H. N., Sigsgaard, C., Soegaard, H., and Tamstorf M. P.: Trends in $\mathrm{CO}_{2}$ exchange in a high Arctic tundra heath 2000-2010, J. Geophys. Res. Biogeosci., 117, G02001, doi:10.1029/2011JG001901, 2012.

Marushchak, M. E., Kiepe, I., Biasi, C., Elsakov, V., Friborg, T., Johansson, T., Soegaard, H., Virtanen, T., and Martikainen, P. J.: Carbon dioxide balance of subarctic tundra from plot to regional scales, Biogeosciences, 10, 437-452, doi:10.5194/bg-10437-2013, 2013.

Massman, W. J.: Advective transport of $\mathrm{CO}_{2}$ in permeable media induced by atmospheric pressure fluctuations: 1. An analytical model, J. Geophys. Res., 111, G03004, doi:10.1029/2006JG000163, 2006.

Massman, W. J. and Frank J. M.: Advective transport of $\mathrm{CO}_{2}$ in permeable media induced by atmospheric pressure fluctuations: 2. Observational evidence under snowpacks, J. Geophys. Res., 111, G03005, doi:10.1029/2006JG000164, 2006.

Mauder, M. and Foken, T.: Documentation and instruction manual of the eddy covariance soft-ware package TK2, University of Bayreuth, Dept. of Micrometeorology, Work Report, 26, Print: ISSN 1614-8916, 2004.

Mauder, M. and Foken, T.: Documentation and instruction manual of the eddy covariance soft-ware package TK3, University of Bayreuth, Dept. of Micrometeorology, Work Report, 46, Print: ISSN 1614-8916, 2011. 
Mauder, M., Liebethal, C., Göckede, M., Leps, J. P., Beyrich, F., and Foken, T.: Processing and quality control of flux data during LITFASS-2003, Bound Lay. Meteorol., 121, 67-88, 2006.

Mauder, M., Oncley, S. P., Vogt, R., Weidinger, T., Riberio, L., Bernhofer, C., Foken, T., Kohsiek, W., DeBruin, H., and Liu, H.: The Energy Balance Experiment EBEX-2000 - Part II: Intercomparison of eddy covariance sensors and post-field data processing methods, Bound Lay. Meteorol., 123, 29-54, 2007.

Mauder, M., Foken, T., Clement, R., Elbers, J. A., Eugster, W., Grünwald, T., Heusinkveld, B., and Kolle, O.: Quality control of CarboEurope flux data - Part 2: Inter-comparison of eddy-covariance software, Biogeosciences, 5, 451-462, doi:10.5194/bg-5-451-2008, 2008.

McDowell, N. G., Marshall, J. D., Hooker, T. D., and Musselman, R.: Estimating $\mathrm{CO}_{2}$ flux from snowpacks at three sites in the Rocky Mountains, Tree Physiol., 20, 745-753, 2000.

Merbold, L., Rogiers, N., and Eugster, W.: Winter $\mathrm{CO}_{2}$ fluxes in a sub-alpine grassland in relation to snow cover, radiation and temperature, Biogeochemistry, 111, 287-302, 2012.

Michaelis, L. und Menten, M.: Die Kinetik der Invertinwirkung, Biochemische Zeitschrift, 49, 333-369, 1913.

Moore, C. J.: Frequency response corrections for eddy correlation systems, Bound. Layer Meteorol., 37, 17-35, 1986.

Nobel, P. S.: Biophysical Plant Physiology, W.H. Freeman and Company, San Francisco, 1983.

Nomura, D., Yoshikawa-Inour, H., Toyota, T., and Shirasawa, K.: Effects of snow, snowmelting and refreezing processes on air-sea-ice $\mathrm{CO}_{2}$ flux, J. Glaciol., 56, 262-270, 2010.

Nordstroem, C., Soegaard, H., Christensen, T. R., Friborg, T., and Hansen, B. U.: Seasonal carbon dioxide balance and respiration of a high-acrtic fen ecosystem in NE-Greenland, Theor. Appl. Climatol., 70, 149-166, 2001.

Oechel, W. C., Hastings, S. J., Vourlitis, G., Jenkins, M., Riechers, G., and Grulke, N.: Recent change of arctic tundra ecosystems from a net carbon dioxide sink to a source, Nature, 361, 520-523, 1993.

Oechel, W. C., Laskowski, C. A., Burba,G., Gioli, B., and Kalhori, A. A. M.: Annual patterns and budget of $\mathrm{CO}_{2}$ flux in an Arctic tussock tundra ecosystem, J. Geophys. Res. Biogeosci., 119, 323-339, 2014.

Ohtsuka, T., Adachi, M., Uchida, M., and Nakatsubo, T.: Relationships between vegetation types and soil properties along a topographical gradient on the northern coast of the Brøgger Peninsula, Svalbard, Polar Biosci., 19, 63-72, 2006.

Oncley, S. P., Foken, T., Vogt, R., Kohsiek, W., DeBruin, H., Bernhofer, C., Christen, A., van Gorsel, E., Grantz, D., Feigenwinter, C., Lehner, I., Liebethal, C., Liu, H., Mauder, M., Pitacco, A., Riberio, L., and Weidinger, T.: The Energy Balance Experiment EBEX-2000 - Part I: overview and energy balance, Bound Lay. Meteorol., 123, 1-28, 2007.

Papale, D., Reichstein, M., Aubinet, M., Canfora, E., Bernhofer, C., Kutsch, W., Longdoz, B., Rambal, S., Valentini, R., Vesala, T., and Yakir, D.: Towards a standardized processing of Net Ecosystem Exchange measured with eddy covariance technique: algorithms and uncertainty estimation, Biogeosciences, 3, 571-583, doi:10.5194/bg-3-571-2006, 2006

Rey, A., Belelli-Marchesini, L., Were, A., Serrano-ortiz, P., Etiope, G., Papale, D., Domingo, F., and Pegoraro, E.: Wind as a main driver of the net ecosystem carbon balance of a semiarid Mediter- ranean steppe in the South East of Spain, Glob. Change Biol., 18, 539-554, 2012.

Roth, K. and Boike, J.: Quantifying the thermal dynamics of a permafrost site near Ny-Ålesund, Svalbard, Water Resour. Res., 37, 2901-2914, 2001.

Ruppert, J., Mauder, M., Thomas, C., and Lüers, J.: Innovative gapfilling strategy for annual sums of $\mathrm{CO}_{2}$ net ecosystem exchange, Agr. Forest Meteorol., 138, 5-18, 2006

Sánchez-Cañete, E. P., Kowalski, A. S., Serrano-Ortiz, P., PérezPriego, O., and Domingo, F.: Deep $\mathrm{CO}_{2}$ soil inhalation / exhalation induced by synoptic pressure changes and atmospheric tides in a carbonated semiarid steppe, Biogeosciences, 10, 6591-6600, doi:10.5194/bg-10-6591-2013, 2013.

Schuur, E. A. G., Vogel, J. G., Crummer, K. G., Lee, H., Sickman, J. O., and Osterkamp, T. E.: The effect of permafrost thaw on old carbon release and net carbon exchange from tundra, Nature, 459, 556-559, 2009.

Seok B., Helmig, D., Williams, M. W., Liptzin, D., Chowanski, K., and Hueber, J.: An automated system for continuous measurements of trace gas fluxes through snow: an evaluation of the gas diffusion method at a subalpine forest site, Niwot Ridge, Colorado, Biogeochemistry, 95, 95-113, 2009.

Shaver, G. R., Street, L. E., Rastetter, E. B., Van Wijk, M. T., and Williams, M.: Functional convergence in regulation of net $\mathrm{CO}_{2}$ flux in heterogeneous tundra landscapes in Alaska and Sweden, J. Ecol., 95, 802-817, 2007.

Soegaard, H. and Nordstroem, C.: Carbon dioxide exchange in a high-arctic fen estimated by edd covariance measurements and modeling, Glob. Change Biol., 5, 547-562, 1999.

Soegaard, H., Nordstroem, C., Friborg, T., Hansen, B., Christensen, T., and Bay, C.: Trace Gas exchange in a High-Arctic Valley 3. Integrating and Scaling $\mathrm{CO}_{2}$ Fluxes From Canopy to Landscape Using Flux Data, Footprint Modeling, and Remote Sensing, Global Biogeochem. Cy., 14, 725-744, 2000.

Tagesson, T., Mölder, M., Mastepanov, M., Sigsgaard, C., Tamstorf, M. P., Lund, M., Falk, J. M., Lindroth, A., Christensen, T. R., and Ström, L.: Land-atmosphere exchange of methane from soil thawing to soil freezing in a high-Arctic wet tundra ecosystem, Glob. Change Biol., 18, 1928-1940, 2012.

Tokida, T., Miyazaki, T., Mizoguchi, M., Nagata, O., Takakai, F., and Kagemoto, A.: Falling atmospheric pressure as a trigger for methane ebullition from peatland, Global Biogeochem. Cy., 21, GB2003, doi:10.1029/2006GB002790, 2007.

Uchida, M., Kishimoto, A., Muraoka, H., Nakatsubo, T., Kanda, H., and Koizumi, H.: Seasonal shift in factors controlling net ecosystem production in a high Arctic terrestrial ecosystem, J. Plant Res., 123, 79-85, 2009.

Vickers, D. and Mahrt, L.: Quality control and flux sampling problems for tower and aircraft data, J. Atmos. Ocean Tech., 14, 512-526, 1997.

Webb, E. K., Pearman, G. I., and Leuning, R.: Correction of the flux measurements for density effects due to heat and water vapour transfer, Quart. J. Roy. Meteorol. Soc., 106, 85-100, 1980.

Westermann, S., Lüers, J., Langer, M., Piel, K., and Boike, J.: The annual surface energy budget of a high-arctic permafrost site on Svalbard, Norway, The Cryosphere, 3, 245-263, doi:10.5194/tc3-245-2009, 2009a.

Westermann, S., Lüers, J., Langer, M., Piel, K., and Boike, J.: Temperature time series and physical properties of snow 
samples of a high-arctic permafrost site on Svalbard, Norway, PANGAEA Data Publisher for Earth Environ. Sci., doi:10.1594/PANGAEA.746722, 2009b.

Westermann, S., Wollschläger, U., and Boike, J.: Monitoring of active layer dynamics at a permafrost site on Svalbard using multichannel ground-penetrating radar, The Cryosphere, 4, 475-487, doi:10.5194/tc-4-475-2010, 2010.
Westermann, S., Boike, J., Langer, M., Schuler, T. V., and Etzelmüller, B.: Modeling the impact of wintertime rain events on the thermal regime of permafrost, The Cryosphere, 5, 945-959, doi:10.5194/tc-5-945-2011, 2011.

Wilczak, J. M., Oncley, S. P., and Stage, S. A.: Sonic anemometer tilt correction algorithms, Bound-Lay. Meteorol., 99, 127-150, 2001.

Zimov, S. A., Davidov, S. P., Voropaev, Y. V., Prosiannikov, S. F., Semiletov, I. P., Chapin, M. C., and Chapin III, F. S.: Siberian $\mathrm{CO}_{2}$ efflux in winter as a $\mathrm{CO}_{2}$ source and cause of seasonality in atmospheric $\mathrm{CO}_{2}$, Clim. Change, 33, 111-120, 1996. 